\title{
ENTREPRENEURIAL MOTIVATIONS AMONG FEMALE UNIVERSITY YOUTH IN SAUDI ARABIA
}

\author{
Wafa N. Almobaireek ${ }^{1}$, Tatiana S. Manolova ${ }^{2}$ \\ ${ }^{1}$ Dean, College of Business and Administration, Princess Nourah bint Abdulrahman University, \\ P.O. Box 84428, Riyadh 11671, Saudi Arabia \\ Business College, King Saud University, P.O. Box 7695, Riyadh 11472, Saudi Arabia \\ ${ }^{2}$ Department of Management, Bentley University, 175 Forest St., Waltham, MA 02452, USA \\ E-mails: ${ }^{1}$ wmobaireek@ksu.edu.sa; ${ }^{2}$ tmanolova@bentley.edu (correspondingauthor)
}

Received 23 January 2012; accepted 09 July 2012

\begin{abstract}
To successfully target potential women entrepreneurs in Saudi Arabia, a better understanding of their entrepreneurial motivations is needed. In this study, we used economic, human development, and social learning perspectives to explore the entrepreneurial motivations among female university youth in Saudi Arabia and formulated three hypotheses on the gender differences in these motivations. We conducted a survey among undergraduate students at King Saud University in Spring'2010 $(\mathrm{n}=856)$ and tested our hypotheses using analysis of variance (chi-square tests and t-tests). Consistent with research on female entrepreneurs around the world, our results indicate that female university youth in Saudi Arabia are more likely than men to start an entrepreneurial venture out of necessity, whereas men are more likely to have a financial success motivation. At the same time, and in contrast to findings from studies on entrepreneurial motivations in the context of Western Europe and the USA, young Saudi university women report a narrower range of entrepreneurial motivations, compared to men. The implications of this exploratory study point to the need for initiatives specifically focused at young women in order to increase their confidence that entrepreneurship is a viable route to accomplish a broad range of career reasons.
\end{abstract}

Keywords: Saudi Arabia, entrepreneurial motivations, women entrepreneurs, university youth, social learning, human development.

Reference to this paper should be made as follows: Almobaireek, W. N.; Manolova, T. S. 2013. Entrepreneurial motivations among female university youth in Saudi Arabia, Journal of Business Economics and Management 14(Supplement 1): S56-S75.

JEL Classification: L26, J16, C12.

\section{Introduction}

Creating a culture of entrepreneurship in Saudi Arabia is a critical priority for national public policy as the country strives to diversify its economic base away from the dependence on crude oil and to provide employment for its burgeoning young population. Entrepreneurship can foster individual self-empowerment and serve as a powerful engine of job creation, economic growth, innovation, organizational adaptation, and constant reinvigoration of economic life (Audretsch 2007; Reynolds 2007). 
A critical component in the promotion of entrepreneurship is the fuller integration of women in economic activities. Saudi women have traditionally remained outside of economic life, restricted to the domestic roles of wives and mothers. Yet, they hold $40 \%$ of the national private wealth, $70 \%$ of the liquid capital, $40 \%$ of the real estate assets, $20 \%$ of the investment funds and portfolios and more than $\$ 13$ billion in local bank accounts that could potentially be invested in the local economy (Almunajjed 2006; Knowledge@ Wharton 2010). Unlocking Saudi women's entrepreneurial potential can significantly contribute to the growth and competitiveness of the national economy and is a matter of considerable public policy importance. Thus, the Ninth Development Plan of the Kingdom (2010-2014) identifies the promotion of the effective participation of Saudi women in the Kingdom's development as one of the major implementation mechanisms of the plan (Ministry of Economy and Planning 2010). The economic involvement of female university graduates is particularly desirable because they have the potential to start high growth and innovative new ventures (Lüthje, Franke 2003).

But what factors motivate young Saudi women to consider engaging in entrepreneurial activities? Currently, there is a dearth of research on the entrepreneurial motivations of female youth in Saudi Arabia and in the broader context of the Middle East (Gallant et al. 2010). The present study aims to address this research gap. Our main premise is that young Saudi women will likely be motivated to engage in entrepreneurial activities by many of the same drivers that promote women's entrepreneurship in other economic, social, and cultural contexts, but the motivation effect would be influenced by the strong traditional restrictions and social expectations.

To explore the multifaceted nature of Saudi female youth's entrepreneurial motivations, we use a combination of economic, human development, and social learning lenses and a comparative approach, contrasting the entrepreneurial motivations of male and female university youth. We test our hypothesis on a sample of undergraduate students from King Saud University, the oldest and largest university in Saudi Arabia. Our results suggest that men and women differ significantly in their entrepreneurial motivations and that social expectations and constraints shape to a significant extent young Saudi women's attitudes towards entrepreneurship. Notably, female university students demonstrate a significantly narrower scope of entrepreneurial motivations compared to their male counterparts.

The article proceeds as follows. After a brief overview of the research context of the study, we present our theoretical arguments and formulate three hypotheses about gender effects on entrepreneurial motivations. We next report our research methodology and test results. We conclude by discussing the study's implications for future research, entrepreneurship education, and public policy.

\section{Research context}

Saudi Arabia has a factor-driven economy with strong government controls over major economic activities. The petroleum sector contributes $80 \%$ of budget revenues, $45 \%$ of GDP, and $90 \%$ of the export earnings. Foreign workers account for about $80 \%$ of the 
labor force, and are engaged primarily in the petroleum and service sectors (The World Factbook 2010).

The diversification of the economic base and the "Saudization" of the labor force are currently two critical priorities for Saudi economic policy. These tasks are exacerbated by the "youth bulge" (roughly half of the Saudi population is younger than 24 years old) and the high unemployment rate in the 15-24 age bracket, which stood at $28.4 \%$ as of 2009 (Ministry of Economy and Planning 2010). Entrepreneurship among university graduates can help alleviate the unemployment among the burgeoning young population, while contributing to economic diversification, innovation, and growth. Women, in particular, hold a significant underutilized economic potential, as they currently account for $57 \%$ of all university graduates, but merely $15 \%$ of the Saudi workforce (Almunajjed 2010).

Recent years have seen a rise in the number of women-owned businesses, which presently comprise about $12 \%$ of all firms in the country, including $16 \%$ of the large manufacturing firms (AlMunajjed 2010). Saudi women have started some very successful entrepreneurial companies. As a case in point, eight of the 45 Fast Growth Companies recognized in 2008 as the biggest contributors to job creation, innovation and growth were founded by women (Porter 2009). A recent study by the Monitor Group on businesswomen in Saudi Arabia (Alturki, Braswell 2010) found that the most common businesses owned by the surveyed Saudi women were art-based, including fashion, jewelry, interior design, and photography. Yet, these businesses were among the largest in the surveyed Middle East and North Africa (MENA) countries, and Saudi women were significantly more likely to be the sole owners of their businesses compared to their MENA counterparts; among the most optimistic about their business prospects; and focused on future business growth. In other words, although Saudi women appear to run predominantly lifestyle businesses, their entrepreneurial motivations are increasingly being shaped by a desire for innovation, growth, and business success. In the following section, we develop our theoretical argument and formulate hypotheses on the gender effects on entrepreneurial motivations in the Saudi context.

\section{Theoretical perspectives and hypothesis development}

Just as the entrepreneur is central to the entrepreneurial process, so are his or her motivations critical in understanding the entrepreneurial phenomenon. The differences in human actors' motivations influence who pursues entrepreneurial opportunities, what the entrepreneurial process looks like, and what the outcomes of the entrepreneurial engagement turn out to be (Locke, Baum 2007; Shane et al. 2003; Shaver, Scott 1991).

Human motivations are important in the process of starting a new venture for at least three reasons. First, as Carsrud and Brännback (2011: 12) argue, "motivations may be the spark that transforms a latent intention into real action, and therefore, the missing link between intentions and action". Second, the type of individual entrepreneurial motivation may determine the goals and aspirations for the firm, such as its focus on growth and innovation, which in turn may determine macroeconomic outcomes (Hessels et al. 
2008). Third, and central to the premise of our paper, if systemic gender differences in entrepreneurial motivations do exist, then public policies can be specifically targeted in order to provide the right incentives for engaging in entrepreneurial initiatives. In sum, a good understanding of human motivations is critical to the study of entrepreneurial intentions and their conversion into value-creating entrepreneurial behaviors.

Two major schools of thought, one based in economics, and the other based in psychology, have produced a "superabundance of motivational theories" (Steel, König 2006: 889), that are often at odds with each other. Starting with the work of the neoclassical theorists of the $19^{\text {th }}$ century, such as Alfred Marshall, neoclassical economic theory is built on the notion of utility as a driving factor in the choices of economic actors. Utility is construed as the individual's inherently unobservable satisfaction or benefit, "correlative of desire or want' (Marshall 1920: 78), and modeled to be affected by the consumption of goods and services, possession of wealth, or spending of leisure time. Material, or monetary gain, is assumed to be the dominant, if not the only, factor affecting utility (Frey 1997).

The psychologists' interest in human motivations, in turn, originates in Freud's (1960 [1901]) work on instincts, in which he argued that unconscious desires and fears, rather than conscious thought, were the principal motivating factors behind behavior. Motivational theories can be classified into drive theories and incentive theories (Carsrud, Brännback 2011). Drive, or "motivational push", theories emphasize the need to resolve the tension caused by discomfort or pain. Incentive, or "motivational pull", theories focus on the role of tangible and intangible rewards and punishments. Incentive theories, in turn, differentiate between extrinsic and internal motivations, driven by external or internal rewards and punishments (Deci 1975). Outcomes such as money, power, or status, are generally regarded as extrinsic (Carsrud, Brännback 2011), whereas the feelings of accomplishment, pride in work, achievement, or personal growth are deemed intrinsic (Deci 1975).

Traditionally, the reasons for engaging in the entrepreneurial process have been considered to be extrinsic and focused on economic gain, although powerful intrinsic motivations such as the need for achievement (McClelland 1961), desire for independence (Hornaday, Aboud 1973), or passion (Cardon et al. 2009) have also been argued to be influential (Shane et al. 2003). For example, in his microtheory of innovative entrepreneurship, Baumol (2010) posits that psychic rewards, such as being one's own boss, pride in self-accomplishment, etc., make the entrepreneurial endeavor worthwhile even if the pecuniary rewards are low.

Overall, people start businesses for a variety of different reasons, and these motivations vary by gender (Kepler, Shane 2007). To explore the complex nature of entrepreneurial motivations in the context of Saudi university youth, we use a combination of economic, human development, and social learning perspectives. We first focus on the "push" versus "pull" entrepreneurial motivations. From an economic perspective, we examine the relative importance of opportunity-based versus necessity-based motivations to engage in entrepreneurship. We next explore entrepreneurship as an occupational choice and 
examine the variety of career reasons to start a new venture using theoretical arguments from the developmental psychology literature, looking at the role of extrinsic versus intrinsic motivations. Finally, we focus on the unique Saudi context and bring in a social learning perspective in order to theorize on the effect of gender socialization experiences on the scope of entrepreneurial motivations.

\subsection{Necessity versus opportunity-based entrepreneurship}

Economists differentiate between two types of motivations to start a new venture: opportunity-based and necessity-based (Minniti et al. 2004; Acs 2006). As defined by the Global Entrepreneurship Monitor (GEM), necessity-based entrepreneurship occurs when individuals participate in entrepreneurial activities because all other employment options are either absent or unsatisfactory (Reynolds et al. 2002). This concept is similar in nature to the negative, or "push" factors that force people into self-employment because of unemployment, underemployment, job dissatisfaction, blocked opportunities, or no opportunities at all (Sadi, Al-Ghazali 2010). Necessity-based entrepreneurship is in contrast to the more desirable opportunity-based entrepreneurship, when the entrepreneur is driven by the achievement of success through exploiting an opportunity for some form of gain, most often economic (Acs et al. 2004). Necessity motives play a major role in developing countries, and, to a lesser extent, in developed countries (Grilo, Thurik 2008). Generally, the GEM studies find that, compared to men, many more women are pushed into entrepreneurship because of the lack of alternative job opportunities (Minniti et al. 2004; Langowitz, Minniti 2007; Elam 2008).

Women are disproportionately pushed into necessity-based entrepreneurship because of the horizontal and vertical labor market segregation restricting the number and type of labor opportunities. Horizontal labor market segregation occurs when women are clustered in a limited number of occupations. Indeed, women mainly occupy the service sector and are over-represented in clerical occupations, sales jobs and life-science/health and teaching professions (Verheul et al. 2006). Vertical labor market segregation occurs when women face challenges in their promotion to top administrative and managerial occupations (Verheul et al. 2006). When women are dissatisfied with their career opportunities (either because they can only work in certain industrial sectors or because their career advancement opportunities are limited), they will be motivated to start their own businesses (Cowling, Taylor 2001; Verheul et al. 2006).

Women currently account for merely $15 \%$ of the Saudi workforce, among the lowest labor participation rates in the world. Although Saudi laws and regulations based on the Shari'a guarantee a woman's right to work, they stipulate that she should work in an appropriate environment - that is, not mixing with men or being exposed to harassment. Sex segregation by occupation is therefore prevalent in Saudi society: women are concentrated in certain professions that are seen as feminine and remain in less distinguished positions than men. Eighty-five percent of all working women are in education, in both teaching and administrative positions.

Unfortunately, high levels of education do not guarantee appropriate employment for Saudi women. Indeed, $78.3 \%$ of the currently unemployed women in the country are 
university graduates and more than 1000 of them have a doctorate. The unemployment rate among women is currently $26.9 \%$, nearly four times that of men ${ }^{1}$. Apparently, both horizontal and vertical labor market segregation prevent young Saudi women from realizing their economic potential. Hence, we hypothesize:

H1: Saudi female university students will be more likely to have a necessity motivation to pursue entrepreneurship compared to men.

\subsection{Career reasons}

A stream of influential work on entrepreneurial motivations has investigated the role of intrinsic and extrinsic motivations (Carsrud, Brännback 2011; Bird 1989; Kuratko et al. 1997; Naffziger et al. 1994). Related work in the field of developmental psychology and career choice (Scheinberg, MacMillan 1988; Shane et al. 1991; Brush 1992; Birley, Westhead 1994) has identified a variety of reasons to start a new venture, which Carter et al. (2003) classified into six categories: self-realization (the pursuit of goals of interest to the entrepreneur), financial success (intention to earn more money and achieve financial security), recognition (achievement of status, approval, and recognition from family, friends, and the community), roles (the desire to follow a family tradition and emulate the example of others), innovation (the intention to accomplish something new), and independence (the desire for freedom, control, and flexibility).

Prior research has established that men are more often motivated by financial and instrumental concerns whereas women are more often motivated by relational and social concerns (Rosa et al. 1996; Fischer et al. 1993) and seek to balance economic goals with other kinds of goals such as personal enjoyment and helping others (Brush 1992; Cliff 1998). Notably, women have been found to be more likely than men to start businesses to achieve a work-family balance (Brush et al. 2006), whereas men are more likely to start businesses in order to make money or build a company (DeMartino, Barbato 2003). Brush (1992) argued that women perceive their businesses as "cooperative networks of relationships" in which business relationships are integrated rather than separated from family, societal, and personal relationships, while men perceive their businesses as economic entities designed to achieve profit through competitive advantage. Indeed, in their study of the role of gender identity for business owners' career satisfier preferences, Eddleston and Powell (2008) established that individuals with a strong masculine orientation preferred status-based outcomes, such as earning a lot of money, having high prestige, growing a world-class business, or leading a large, rapidly growing enterprise; whereas individuals with a strong feminine orientation favored harmonious employee relationships and contributing to society.

Research on the entrepreneurial motivations of Saudi women is extremely limited. A recent study by Sadi and Al-Ghazali (2010) found that self-achievement was the most important motivational factor for Saudi business women, followed by the desire to work independently; whereas the profit motive was ranked fourth among eight potential rea-

\footnotetext{
${ }^{1}$ The discussion of the participation of Saudi women in the labor force draws upon Booz and Co.'s 2010 report on women's employment in Saudi Arabia (Almunajjed 2010).
} 
sons to start a new venture. Research in the broader context of women's entrepreneurship in the Middle East has similarly established that women seek to fulfill a variety of intrinsic personal goals in starting their new ventures. Thus, Shabbir and Di Gregorio (1996), in their study of 33 participants of an entrepreneurship development program in Karachi, Pakistan found that the women wanted to start a business in order to achieve three types of personal goals: personal freedom, security, and satisfaction. A study of 25 Omani women-entrepreneurs (McElwee, Al-Riyami 2003) reported that the interviewees prioritized enjoyment, though economic necessity was a key motivational factor for divorced women. Similarly, in their case studies of six Bahraini and six Omani womenentrepreneurs, Dechant and Al Lamsky (2005) identified a combination of "push" and "pull" factors, with the predominant entrepreneurial motivations being the nature of the opportunity, the need for achievement, self-fulfillment and the desire to help others. All of these findings echo research from other regions of the world in that women appear more likely than men to be drawn into entrepreneurship by intrinsic motivations, such as gaining independence, enjoyment, altruism, and self-fulfillment. This is not to say that women are indifferent to pecuniary rewards; just that the financial motivation is not as prevalent as among men. Formally:

H2: Saudi female university students will be less likely to have a financial success motivation to pursue entrepreneurship compared to men.

\subsection{Social learning}

Social learning theory (Bandura 1977; Harriman 1985) suggests that differing social expectations for men and women lead to divergent motivations or work preferences. Bussey and Bandura (1999) argue that a variety of factors influence gender development (e.g., peers, media, educational practices, occupational systems) and explain differences in women's and men's socialization. For example, as a result of women's different socialization experiences, they may lack strong expectations of personal efficacy toward many career related behaviors, and therefore may not fully attain their potential (Bandura 1977). Further, sex-role socialization experiences teach young girls what gender roles are appropriate for them and what are not. These experiences are seen as constricting career choices and compromising their career potential (Gottfredson 1981). Women are seen as experiencing more complexity in making career choices because of their need to balance employment, child care, and housing (Carter et al. 2003). The career choices become even more complex when women entrepreneurs need to negotiate and navigate patriarchal families with traditional values and well-defined gender roles (AlDajani, Marlow 2010).

Strict expectations about gender roles shape young women's socialization experiences in the Muslim societies of the Middle East. Women are expected to be first and foremost wives, mothers, and homemakers, while men are expected to provide for and protect their families (McIntosh, Islam 2010). Male power does not just rest upon an economic justification, such as the "breadwinner" identity, rather, it is culturally, religiously, socially, and politically embedded (Civettini, Glass 2008; Rees, Althakhri 2008). The traditional patriarchal family upholds this socio-economic order, reproduces gender hierarchies and legitimizes female subordination (Al-Dajani, Marlow 2010). 
In Saudi Arabia, the gender ideology promoted in the political culture idealizes women's domesticity and elevates sex segregation (Mostafa 2005). Although Saudi women increasingly have access to a well-rounded education, and the right to work, they do not have the full opportunity to participate appropriately in economic life (Almunajjed 2010) and are restricted in their participation in political and social life (Alturki, Braswell 2010). In addition, the relatively recent phenomenon of women's entrepreneurship has not provided enough role models of successful women-entrepreneurs in order to reinforce the pursuit of entrepreneurial initiatives as a legitimate and desirable career path. In a 2006 interview, Princess Monira bint Abdul Rahman bin Abdulla al Saud, a co-founder of the Charity Center for Social Guidance and Family Consultations in Riyadh, observed: "Although we have outstanding Saudi women in our society, we still have a number of other Saudi women who have great potential but are not very active or do not use it, perhaps due to personal or cultural social reasons" (Almunajjed 2006: 253). In sum, female youth in Saudi Arabia may consider entrepreneurship as an inappropriate gender role or may doubt they have the necessary qualifications and skills to successfully pursue entrepreneurial initiatives. Even if the level of confidence in their entrepreneurial abilities is high, they may doubt if their business endeavor will earn social support or recognition. As a result, we surmise that some traditional entrepreneurial motivations such as the need for achievement, social recognition, or gaining a prominent social position may be deemed irrelevant by aspiring young female entrepreneurs in Saudi Arabia. Hence, we hypothesize:

H3: Saudi female university students will have a narrower range of entrepreneurial motivations compared to men.

\section{Methodology}

\subsection{Data collection and sample characteristics}

The data for the study come from a unique survey of entrepreneurial motivations among Saudi university youth, collected from undergraduate students at King Saud University (the oldest and largest Saudi University) in the Spring of 2010. Established in Riyadh in 1957, with a student population of over 70000 undergraduate and graduate students in 24 humanities and science colleges (including two women's colleges), King Saud University (KSU) is the oldest and largest Saudi university, and the highest ranked university in the Middle East in the 2010 Academic Rankings of World Universities (APWU). The university has 15 research centers and a wide variety of programs aimed at knowledge creation, dissemination, and commercialization. Thus, we expected that KSU undergraduates would perceive entrepreneurship as a desirable and feasible career path.

We collected data through a survey. Data collection through surveys is the preferred methodology in the study of entrepreneurial motivations (Carter et al. 2003; Kourilsky, Walstad 1998). The survey was compiled based on prior instruments developed in the study of entrepreneurial motivations (Scheinberg, MacMillan 1988; Shane et al. 1991; Brush 1992; Birley, Westhead 1994; Acs et al. 2004) and administered in Arabic to 
random undergraduate student sections in the male and female campuses of the university. Semantic equivalency was established through translation into English and back translation into Arabic, following the recommendations and procedure suggested by Graham et al. (1994). The surveys were paper-based and administered in a classroom setting to maximize the response rate. In addition to questions related to entrepreneurial motivations, the survey included sections on perceived start-up problems, as well as self-assessed qualifications and skills.

We obtained responses from 599 men and 353 women, to a total initial sample size of $n=952$. The respondents ranged in age between 18-24 and were all Saudi nationals. Slightly over $12 \%$ of the respondents reported they had started a business before (11\% among women and $13.40 \%$ among men), and only $7.7 \%$ of them $(13.60 \%$ among women and $4.19 \%$ among men) stated they had any qualification and training to start a new business. Out of the initial sample, 856 respondents $(88.07 \%$ among women and $91.44 \%$ among men) stated they would like to start their own business. These 856 respondents comprise the final study sample, for which we report descriptive statistics as well as results from the statistical testing.

\subsection{Measures}

Combining prior research on entrepreneurial motivations (Scheinberg, MacMillan 1988; Shane et al. 1991; Brush 1992; Birley, Westhead 1994) with research on opportunity and necessity-based entrepreneurship (Acs et al. 2004), we compiled a list of eleven entrepreneurial motivations and asked the respondents to check off the most important reasons to start a new venture. Thus, entrepreneurial motivations were measured by 11 binary items, as follows: financial gain, necessity, independence, providing jobs, higher social position, flexibility, creativity, gaining experience, achievement, higher control, and achieving a personal vision. The range of entrepreneurial motivations, in turn, was measured by summing up the tallies of all reasons to start a new venture $(\mathrm{M}=4.01$, $\mathrm{SD}=2.08$ ). Table 1 provides the frequencies and descriptive statistics for all measures used in the study. All survey items are listed in Appendix A.

\section{Results}

Hypotheses $\mathrm{H} 1$ and $\mathrm{H} 2$ stated that there will be differences in the entrepreneurial motivations between men and women, in that women will be more likely to have a necessity motivation to start a new business (H1), whereas men will be more likely to have a financial motivation (H2). Since both our independent variable (gender) and our dependent variables (motivations) were binary, we tested these two hypotheses by crosstabulating the eleven binary entrepreneurial motivations by gender (Hair et al. 2009). The results, presented in Table 2, show that even though necessity did not rank high as an entrepreneurial motivation for either males or females, close to $12 \%$ of the women cited it as a reason to start a new venture, compared to only $8.4 \%$ of the men. Thus, $\mathrm{H} 1$ was supported at the $\mathrm{p}<.1$ significance level. In contrast, even though financial gain was identified by the respondents as the number one entrepreneurial motivation for both men and women, close to $90 \%$ of the men $(89.19 \%)$ cited it as a reason to start a new 
Table 1. Descriptive statistics $(\mathrm{n}=856)^{*}$

\begin{tabular}{|c|c|c|c|c|c|}
\hline \multirow[t]{3}{*}{ Variable } & \multirow[t]{3}{*}{$\mathrm{N}$} & \multicolumn{4}{|c|}{ Frequencies and Descriptives } \\
\hline & & & Male & & \\
\hline & & & Count & Percent & \\
\hline Gender & 856 & & 546 & $63.79 \%$ & \\
\hline \multirow[t]{2}{*}{ Entrepreneurial Motivations } & & & Yes & & \\
\hline & & & Count & Percent & \\
\hline Financial gain & 856 & & 704 & $82.24 \%$ & \\
\hline Necessity & 856 & & 83 & $9.70 \%$ & \\
\hline Independence & 856 & & 336 & $39.25 \%$ & \\
\hline Provide jobs & 856 & & 169 & $19.74 \%$ & \\
\hline Social position & 856 & & 296 & $34.58 \%$ & \\
\hline Flexibility & 856 & & 204 & $23.83 \%$ & \\
\hline Creativity & 856 & & 433 & $50.58 \%$ & \\
\hline Experience & 856 & & 382 & $44.63 \%$ & \\
\hline Achievement & 856 & & 370 & $43.22 \%$ & \\
\hline Control & 856 & & 230 & $26.87 \%$ & \\
\hline \multirow[t]{2}{*}{ Vision } & 856 & & 223 & $26.05 \%$ & \\
\hline & $\mathrm{N}$ & Min & Max & Mean & $\mathrm{SD}$ \\
\hline Range of Motivations & 856 & 0 & 11 & 4.01 & 2.08 \\
\hline
\end{tabular}

Note: * only those who stated they would like to start a new business

Table 2. Entrepreneurial motivations: crosstabs and T-test by gender $(\mathrm{N}=856)^{1}$

\begin{tabular}{|c|c|c|c|c|c|}
\hline & \multicolumn{2}{|c|}{ Male $(n=546)$} & \multicolumn{2}{|c|}{ Female $(\mathrm{n}=310)$} & \multirow{3}{*}{$\begin{array}{c}\text { Test } \\
\text { of } \\
\text { Significance }\end{array}$} \\
\hline & \multirow{2}{*}{$\frac{\text { Yes }}{\text { Count }}$} & \multicolumn{3}{|c|}{ Yes } & \\
\hline & & Percent & Count & Percent & \\
\hline Entrepreneurial Motivations & & & & & $\chi^{2}$ \\
\hline Financial gain & 487 & $89.19 \%$ & 217 & $70.00 \%$ & $49.88 * * *$ \\
\hline Necessity & 46 & $8.42 \%$ & 37 & $11.94 \%$ & $2.78^{b}$ \\
\hline Independence & 202 & $37.00 \%$ & 134 & $43.23 \%$ & $3.22^{\mathrm{b}}$ \\
\hline Provide jobs & 108 & $19.78 \%$ & 61 & $19.68 \%$ & 0.01 \\
\hline Social position & 208 & $38.10 \%$ & 88 & $28.39 \%$ & $8.24 * *$ \\
\hline Flexibility & 147 & $26.92 \%$ & 57 & $18.39 \%$ & $7.94 * *$ \\
\hline Creativity & 275 & $50.37 \%$ & 158 & $50.97 \%$ & 0.03 \\
\hline Experience & 251 & $45.97 \%$ & 131 & $42.26 \%$ & 1.1 \\
\hline Achievement & 339 & $62.09 \%$ & 31 & $10.00 \%$ & $218.61 * * *$ \\
\hline Control & 202 & $37.00 \%$ & 28 & $9.03 \%$ & $78.69 * * *$ \\
\hline Vision & 190 & $34.80 \%$ & 33 & $10.65 \%$ & $59.88 * * *$ \\
\hline \multirow[b]{2}{*}{ Range of Motivations } & Mean & SD & Mean & SD & t-test \\
\hline & 4.49 & 2.16 & 3.14 & 1.59 & $9.61 * * *$ \\
\hline
\end{tabular}

Notes: ${ }^{1}$ only those who stated they would like to start a new business; Significant at $\mathrm{p}<.1$; * significant at $\mathrm{p}<.05 ; * *$ significant at $\mathrm{p}<.01, * * *$ significant at $\mathrm{p}<.001$. 
business, compared to $70 \%$ of the women, a significant difference. Thus, $\mathrm{H} 2$ was fully supported. Hypotheses 3 stated that men will have a broader range of entrepreneurial motivations compared to women. Since our independent variable (gender) was binary and our independent variable was continuous, we performed a T-test on the range of motivations by gender (Hair et al. 2009). We found a significant difference in the number of reasons to start a new venture between men and women. The results, presented in Table 2, show that men cited on average 4.49 reasons to start a new venture, compared to 3.14 among women. Thus, Hypothesis 3 was also supported.

\section{Discussions}

In this study, we set out to explore the entrepreneurial motivations among female Saudi youth, a woefully under-researched topic, yet one with important public policy implications. We find that young men and women in Saudi Arabia share some similarities in their entrepreneurial orientations, as both groups place high importance on the ability to achieve financial success, show creativity, and gain business experience. Yet, there are some striking differences in their entrepreneurial motivations, as well. Notably, women are less likely to start a new venture for achievement, control, or to realize a vision. In contrast, they are more likely to start a new venture in order to achieve independence. Below, we discuss the findings from the test of our three hypotheses.

We found that relatively few of our respondents cite necessity as a motivation to engage in entrepreneurial activities. Among men, one in twelve cited necessity as a reason to engage in entrepreneurial activity, whereas among women the ratio was one to eight. This finding is actually not surprising, because Saudi Arabia, with a 2009 per capita GDP of $\$ 20,600$, ranks in the top third of the world economies in terms of income (World Factbook 2010). Generally, the ratio of necessity to opportunity entrepreneurship decreases with the level of economic development (Acs 2006; Reynolds et al. 2002). Indeed, the Global Entrepreneurship Monitor reported that only 12\% of the total entrepreneurship activity in Saudi Arabia in 2009 was driven by necessity (Bosma, Levie 2009).

Still, as hypothesized, we also found that female respondents were more likely than male respondents to cite necessity as a reason to start a new venture. This echoes findings across multiple national settings from the Global Entrepreneurship Monitor, which reported that many more women are involved in entrepreneurship because of the lack of alternative job opportunities (Minniti et al. 2004; Langowitz, Minniti 2007). The gender segregation of the Saudi labor market, coupled with women's low labor participation rate and high rates of unemployment all contribute to the disproportionately higher "push" effect for women into necessity entrepreneurship. We surmise this disproportionate "push" effect will be even higher among the general population compared to the relatively more affluent college students who comprise the sample for our exploratory study.

Close to $90 \%$ of the male respondents cited financial gain as a reason to start a new venture, compared to $70 \%$ of the female respondents, a significant difference. This finding supports prior research which has established male entrepreneurs are much more 
likely than female entrepreneurs to state the desire to make money or build a company as the reasons they started their businesses (DeMartino, Berbato 2003; Kepler, Shane 2007) and much more likely to place higher value on the financial aspects of employment (Jurik 1998).

At the same time, it is important to note that financial success was identified by both men and women as the number one motivation to start a business. As mentioned above, almost $90 \%$ of the male respondents identified financial gain as the reason to start a new venture, whereas the second most important motivation (achievement) was identified by $62.09 \%$. Similarly, $70 \%$ of the female respondents identified financial gain as the reason to start a new venture, whereas the second most important motivation (creativity) was identified by $50.97 \%$. In other words, although not as pronounced as for men, the financial success motivation is still a very important reason for female Saudi youth to engage in entrepreneurship initiatives.

Perhaps the most intriguing finding from our study was the wide variance in the range and type of entrepreneurial motivations between young men and women in Saudi Arabia. As hypothesized, we found that Saudi men have a broader range of entrepreneurial motivations, compared to women. This result contrasts findings documented by research in the context of Western economies, where women have been found to be driven by a broader range of entrepreneurial motivations compared to men (Manolova et al. 2012; Schiller, Crewson 1997).

While we did surmise that young Saudi women, because of the significant social constraints and challenges they face, will be driven by a narrower range of entrepreneurial motivations, we did not quite expect that the differences in the motivations of men and women would be so pronounced. However, as Table 2 illustrates, almost two-thirds of the male respondents associated starting a new venture with achievement, compared to only around ten percent of the female respondents. In fact, achievement was the second most important motivation for men to engage in entrepreneurship (after financial gain), whereas for women it was ranked as the second least important motivation. Similarly, over a third of the male respondents associated control and the achievement of a vision as important motivations to start a new venture, compared to around ten percent of the female respondents. Although the contrast is not as stark, it is also worth noting that $38 \%$ of the male respondents believed entrepreneurship would allow them to gain a more prominent social position, compared to $28 \%$ of the female respondents, another significant difference. Overall, we find that the young university women in our sample did not believe their engagement in entrepreneurship would allow them to gain social recognition, achievement, or to realize a vision. In contrast, they saw entrepreneurship as a path to gain independence. Indeed, in addition to necessity, independence was the only other entrepreneurial motivation selected by a significantly higher proportion of women $(43 \%)$ than men $(37 \%)$.

These findings are in contrast to research in the context of the developed Western market economies which has established that women are more likely than men to say they started their businesses precisely in order to gain the recognition of others (Shane 
et al. 1991; Fischer et al. 1993) or from a desire for self-fulfillment (Jurik 1998). The divergent findings from research in other contexts lead us to propose that social restrictions shape to a significant extent the experiences of aspiring young Saudi female entrepreneurs. Indeed, the recent study of the characteristics, challenges, and aspirations of Saudi businesswomen (Alturki, Braswell 2010: 24) revealed that, compared to their MENA counterparts, a higher percentage of the Saudi respondents reported that joining formal networks, dealing with bureaucracy, interference in paperwork, balancing work and family life, gaining access to capital, and managing male employees were "more challenging as a woman". If the level of social and economic restrictions is high and the level of social recognition of women's economic achievements is low, then traditional motivations to pursue entrepreneurship such as realizing a vision or achieving a desirable social status may stop to play a role in drawing young women towards entrepreneurship.

To some extent, our findings may be driven by the context of our study and the nature of our respondents, who are still in the process of completing their education and without professional or start-up experience. Recall that Sadi and Al-Ghazali (2010) in their recent study of Saudi women business owners found that self-achievement was their most important entrepreneurial motivation. It may be possible that the aspiring young female entrepreneurs in our sample lack self-confidence and doubt they would gain achievement or social recognition through their future entrepreneurial endeavors. Practicing women entrepreneurs, however, enhance their self-confidence and the belief that self-achievement is possible through entrepreneurial initiatives.

\section{Limitations and directions for future research}

This study has several limitations, which need to be taken into consideration when its findings are interpreted and generalized. Our sample, consisting of undergraduate students from a single university, is a potential source of selection bias. In particular, the career reasons to pursue entrepreneurship among university students may differ from the motivations of more mature respondents, whose perspectives have been shaped by work and life experiences. Thus, we acknowledge the exploratory nature of our investigation. A future study based on pure random or stratified random sampling, including other regions of the country, would permit robust statistical corroboration and generalization of the study results.

In addition, future studies should explore in more depth the effects of family, cultural, and institutional embeddedness on the entrepreneurial motivations of young Saudi women. We call for in-depth case studies to probe deeper into the drivers of the motivations documented by our exploratory study. Of particular interest is what "achievement" and "independence" mean to Saudi women at different stages of their life and careers.

A broader question for further cross-cultural research is how different or similar the entrepreneurial motivations among female youth are among a diverse array of countries whose cultural and institutional environments are shaped by the Islamic tradition. Future comparative studies can provide a finer-grained analysis of the differences in institu- 
tional and cultural context that female entrepreneurs face in different countries and, equally importantly, possible differences in how they resolve entrepreneurial challenges. Another research question is whether these differences are shrinking or remain stable in the long run, and whether reforms and modernization lead to substantial convergence or important idiosyncrasies will be preserved.

\section{Implications and conclusions}

Limitations notwithstanding, our study has important implications for public policy and the entrepreneurial training of female youth in Saudi Arabia, where women still face significant challenges and restrictions in their social realization. With respect to public policy, initiatives to foster opportunity and necessity entrepreneurs vary greatly in their scope and content. Notably, the state can use funds to promote entrepreneurship as a way out of unemployment and thereby (almost exclusively) support necessity entrepreneurs. Some scholars have challenged the wisdom of such a public policy and have strongly advocated selectivity and support of high growth potential entrepreneurial ventures (Acs 2006; Shane 2009). The creation of an entrepreneurship-friendly institutional regime, coupled with availability of resources, particularly progress in technology, all tend to spur opportunity-based entrepreneurship. Apparently, a balance of public policy approaches is needed in order to gradually shift the focus to the more economically and socially desirable opportunity-based entrepreneurial initiatives among women.

With respect to the need for targeted entrepreneurship education and training, we found that although close to $90 \%$ of the undergraduate students in our sample expressed interest in starting a new venture, less than $10 \%$ had undergone any formal training or developed the requisite skills to engage in entrepreneurial activities. These results provide evidence in support of the need to initiate or improve entrepreneurship education and training (Grüner, Neuberger 2006), particularly for women (Alvarez-Herranz et al. 2011). As Kourilsky and Walstad (1998) suggested in their study of female US youth, targeted entrepreneurship training is particularly needed in order to enhance young women's confidence as entrepreneurs and managers, as prior research has indicated that women generally demonstrate lower confidence in their abilities and exhibit lower self-efficacy. In the context of female university youth in the Middle East, Gallant et al. (2010) reported that female university students in Dubai were positive about the role universities can play in fostering interest towards entrepreneurship and called for specialized entrepreneurial business programs and "hands-on" entrepreneurship experiences to be included in the business studies programs. The more confident young women feel in their abilities as managers, leaders, and entrepreneurs, the more likely they would be to embark on an entrepreneurial career.

Notably, we found that female youth in Saudi Arabia were significantly less likely to identify achievement, control, or the realization of a vision as viable entrepreneurial motivations. On the one hand, that may be the consequence of lower self-efficacy, in that young Saudi women feel they lack the knowledge and skills to achieve great success through their future entrepreneurial initiatives. If this is indeed the case, the 
need for targeted entrepreneurial education is even more pressing. On the other hand, our findings may also reflect the effect of cultural biases and social constraints forcing young Saudi women to doubt that their participation in economic activities would be encouraged or socially recognized. There are, in fact, Saudi women who successfully lead some of the world's largest companies. For example, Mrs. Lubna Olayan, the CEO of the Olayan Financing Company was recognized as N 29 on the Global 2010 Fortune list of the most powerful women in business (Fortune 2010). Thus, we call for public policy initiatives specifically targeted at upholding the image of Saudi womenentrepreneurs and business-owners and celebrating their achievements. Business forums featuring high-profile women in business and increased media exposure will promote powerful role-models for young Saudi women and will enhance the social desirability of an entrepreneurial career.

In conclusion, the implications of this exploratory study point to the need for initiatives specifically focused at young women in order to increase their confidence that entrepreneurship is a viable route to accomplish a broad range of career reasons. The Global Entrepreneurship Monitor (GEM) reports a strong positive correlation between the entrepreneurship activity for women and the total national entrepreneurship activity (Minniti et al. 2004). The more (and stronger) the motivations to embark on an entrepreneurial journey, the greater the likelihood that more young Saudi women will consider it a legitimate and desirable route for self-realization.

\section{Acknowledgements}

This study was undertaken while the second author was a Visiting Professor at King Saud University, Riyadh, Saudi Arabia. The financial support of the Visiting Professors Program at King Saud University is hereby gratefully acknowledged.

\section{References}

Acs, Z. J. 2006. How is entrepreneurship good for economic growth?, Innovations 1(1): 97-107. http://dx.doi.org/10.1162/itgg.2006.1.1.97

Acs, Z. J.; Arenius, P.; Hay, M.; Minniti, M. 2004. Global entrepreneurship monitor: 2004 executive report. Babson Park MA: Babson College and London UK: London Business School.

Al-Dajani, H.; Marlow, S. 2010. Impact of women's home-based enterprise on family dynamics: evidence from Jordan, International Small Business Journal 28(5): 470-486.

http://dx.doi.org/10.1177/0266242610370392

Almunajjed, M. 2006. Saudi women speak: twenty-four remarkable women tell their success stories. Beirut, Lebanon: Arab Institute for Research and Publishing.

Almunajjed, M. 2010. Women's employment in Saudi Arabia: a major challenge [online], [cited 19 September 2010]. Riyadh, Saudi Arabia: Booz \& Co. Available from Internet: http://www. booz.com/media/uploads/Womens_Employment_in_Saudi_Arabia.pdf

Alturki, N.; Braswell, S. 2010. Businesswomen in Saudi Arabia: characteristics, challenges, and aspirations in a regional context. Jeddah, Saudi Arabia: Al-Sayedah Khadijah Bint Khuwailid Businesswomen Center and Riyadh, Saudi Arabia: Monitor Group.

Alvarez-Herranz, A.; Martinez-Ruiz, M. P.; Valencia-De-Lara, P. 2011. How entrepreneurial characteristics influence company creation: a cross-national study of 22 countries tested with panel 
methodology, Journal of Business Economics and Management 12(3): 529-545. http://dx.doi.org/10.3846/16111699.2011.599409

Audretsch, D. 2007. Entrepreneurship capital and economic growth, Oxford Review of Economic Policy 23(1): 63-78. http://dx.doi.org/10.1093/oxrep/grm001

Bandura, A. 1977. Social learning theory. Englewood Cliffs, NJ: Prentice Hall.

Baumol, W. L. 2010. The microtheory of innovative entrepreneurship. Princeton, NJ: Princeton University Press.

Bird, B. 1989. Entrepreneurial behavior. Glenview, IL: Scott Foresman and Company.

Birley, S.; Westhead, P. 1994. A taxonomy of business start-up reasons and their impact on firm growth and size, Journal of Business Venturing 9(1): 7-31.

http://dx.doi.org/10.1016/0883-9026(94)90024-8

Bosma, N.; Levie, J. 2009. Global entrepreneurship monitor: 2009 executive report. Babson Park, MA: Babson College.

Brush, C. G. 1992. Research on women business owners: past trends, a new perspective and future directions, Entrepreneurship Theory and Practice 16(4): 5-30.

http://dx.doi.org/10.4337/9781845429942

Brush, C. G.; Carter, N. M.; Gatewood, E.; Hart, M. 2006. Growth-oriented women entrepreneurs and their businesses. Cheltenham, UK: Edward Elgar.

Bussey, K.; Bandura, A. 1999. Social cognitive theory of gender development and differentiation, Psychological Review 106(4): 676-713. http://dx.doi.org/10.1037/0033-295X.106.4.676

Cardon, M.; Wincent, J.; Singh, J.; Drnovsek, M. 2009. The nature and experience of entrepreneurial passion, Academy of Management Review 34(3): 511-532.

http://dx.doi.org/10.5465/AMR.2009.40633190

Carsrud, A.; Brännback, M. 2011. Entrepreneurial motivations: what do we still need to know?, Journal of Small Business Management 49(1): 9-26.

http://dx.doi.org/10.1111/j.1540-627X.2010.00312.x

Carter, N. M.; Gartner, W. B.; Shaver, K. G.; Gatewood, E. J. 2003. The career reasons of nascent entrepreneurs, Journal of Business Venturing 18(1): 13-39.

http://dx.doi.org/10.1016/S0883-9026(02)00078-2

Civettini, N.; Glass, J. 2008. The impact of religious conservatism on men's work and family involvement, Gender and Society 22(2): 172-194. http://dx.doi.org/10.1177/0891243207310714

Cliff, J. E. 1998. Does one size fit all? Exploring the relationship between attitudes towards growth, gender and business size, Journal of Business Venturing 13(6): 523-542.

http://dx.doi.org/10.1016/S0883-9026(97)00071-2

Cowling, M.; Taylor, M. 2001. Entrepreneurial women and men: two different species?, Small Business Economics 16(3): 167-175. http://dx.doi.org/10.1023/A:1011195516912

Dechant, K.; Al Lamky, A. 2005. Toward an understanding of Arab women entrepreneurs in Bahrain and Oman, Journal of Developmental Entrepreneurship 10(2): 123-140.

http://dx.doi.org/10.1142/S1084946705000100

Deci, E. L. 1975. Intrinsic motivation. New York: Plenum Press.

http://dx.doi.org/10.1007/978-1-4613-4446-9

DeMartino, R.; Barbato, R. 2003. Differences between women and men MBA entrepreneurs: exploring family flexibility and wealth creation as career motivators, Journal of Business Venturing 18(6): 815-832. http://dx.doi.org/10.1016/S0883-9026(03)00003-X

Eddleston, K. A.; Powell, G. N. 2008. The role of gender identity in explaining sex differences in business owners' career satisfier preferences, Journal of Business Venturing 23(2): 244-256. http://dx.doi.org/10.1016/j.jbusvent.2006.11.002 
Elam, A. B. 2008. Gender and entrepreneurship: a multilevel theory and analysis. Cheltenham, UK: Edward Elgar Publishing. http://dx.doi.org/10.1108/01443330110789727

Fischer, E. M.; Reuber, R.; Dyke, L. 1993. A theoretical overview and extension of research on sex, gender, and entrepreneurship, Journal of Business Venturing 8(2): 151-168.

http://dx.doi.org/10.1016/0883-9026(93)90017-Y

Fortune. 2010. 50 Most Powerful Women in Business [online], [cited 21 November 2010]. Available from Internet: http:/money.cnn.com/magazines/fortune/mostpowerfulwomen/2010/global/

Freud, S. (1960[1901]). The standard edition of the complete psychological works of Sigmund Freud. London: Hogarth Press.

Frey, B. 1997. Not just for the money: an economic theory of personal motivation. Cheltenham, UK: Edgar Elgar Publishing.

Gallant, M.; Majumdar, S.; Varadarajan, D. 2010. Outlook of female students towards entrepreneurship: an analysis of a selection of business students in Dubai, Education, Business and Society: Contemporary Middle Eastern Issues 3(3): 218-230.

http://dx.doi.org/10.1108/17537981011070127

Gottfredson, L. 1981. Circumsription and compromise: a developmental theory of occupational aspirations, Journal of Counseling Psychology 28(6): 545-579.

http://dx.doi.org/10.1037/0022-0167.28.6.545

Graham, J. L.; Mintu, A. T.; Rodgers, W. 1994. Explorations of negotiation behaviors in ten foreign cultures using a model developed in the United States, Management Science 40(1): 72-95. http://dx.doi.org/10.1287/mnsc.40.1.72

Grilo, I.; Thurik, R. 2008. Determinants of entrepreneurial engagement levels in Europe and the US, Industrial and Corporate Change 17(6): 1113-1145. http://dx.doi.org/10.1093/icc/dtn044

Grüner, H.; Neuberger, L. 2006. Entrepreneurs' education: critical areas for the pedagogicaldidactic agenda and beyond, Journal of Business Economics and Management 7(4): 163-170.

Hair, J. F.; Black, W. C.; Babin, B. J.; Anderson, R. E. 2009. Multivariate data analysis. $7^{\text {th }}$ ed. Upper Saddle River, NJ: Prentice Hall.

Harriman, A. 1985. Women/men/management. New York, NY: Praeger.

Hessels, J.; van Gelderen, M.; Thurik, R. 2008. Entrepreneurial aspirations, motivations, and their drivers, Small Business Economics 31: 323-339. http://dx.doi.org/10.1007/s11187-008-9134-x

Hornaday, J. A.; Aboud, J. 1973. Characteristics of successful entrepreneurs, Personnel Psychology 24: 141-153. http://dx.doi.org/10.1111/j.1744-6570.1971.tb02469.x

Jurik, N. 1998. Getting away and getting by: the experiences of self-employed homemakers, Work and Occupations 25(11): 7-35. http://dx.doi.org/10.1177/0730888498025001002

Kepler, E.; Shane, S. 2007. Are male and female entrepreneurs really that different? Small business research summary [online], [cited 2 September 2010]. Available from Internet: core.kmi. open.ac.uk/download/pdf/7372331

Knowledge@Wharton. 2010. How women entrepreneurs are driving business in the Middle East [online], [cited 19 September 2010]. Available from Internet: http://knowledgewhartonupennedu/ arabic/articlecfm?articleid $=2445$

Kourilsky, M. L.; Walstad, W. B. 1998. Entrepreneurship and female youth: knowledge attitudes, gender differences, and educational practices, Journal of Business Venturing 13(1): 77-88. http://dx.doi.org/10.1016/S0883-9026(97)00032-3

Kuratko, D.; Hornsby, J.; Naffziger, D. 1997. An examination of owner's goals in sustaining entrepreneurship, Journal of Small Business Management 35(1): 24-33.

Langowitz, N.; Minniti, M. 2007. The entrepreneurial propensity of women, Entrepreneurship Theory and Practice 31(3): 341-364. http://dx.doi.org/10.1111/j.1540-6520.2007.00177.x 
Locke, E. A.; Baum, J. R. 2007. Entrepreneurial motivations, in J. R. Baum, M. Frese, R. A. Baron (Eds.). The psychology of entrepreneurship. Mahwah, NJ: Erlbaum, 93-112.

Lüthje, C.; Franke, N. 2003. The making of an entrepreneur: testing a model of entrepreneurial intent among engineering students at MIT, RandD Management 33(2): 135-147.

Manolova, T. S.; Brush, C. G.; Edelman, L. F.; Shaver, K. G. 2012. One size doesn't fit all: entrepreneurial expectancies and growth intentions of US women and men nascent entrepreneurs, Entrepreneurship and Regional Development 24(1-2): 7-27.

http://dx.doi.org/10.1080/08985626.2012.637344

Marshall, A. 1920. Principles of economics. An introductory volume. $8^{\text {th }}$ ed. London: Macmillan. McClelland, D. C. 1961. The achieving society. Princeton, NJ: Van Nostrand.

McElwee, G.; Al-Riyami, R. 2003. Women entrepreneurs in Oman: some barriers to success, Career Development International 8(7): 339-346. http://dx.doi.org/10.1108/13620430310505296

McIntosh, J. C.; Islam, S. 2010. Beyond the veil: the influence of Islam on female entrepreneurship in a conservative Muslim context, International Management Review 6(1): 102-111.

Minniti, M.; Arenius, P.; Langowitz, N. 2004. Global entrepreneurship monitor: 2004 report of women and entrepreneurship. Wellesley MA: The Center for Women's Leadership at Babson College.

Ministry of Economy and Planning of the Kingdom of Saudi Arabia. 2010. Brief Report on the Ninth Development Plan 1431/32-1435/36 (2010-2014) [online], [cited 21 November 2010]. Available from Internet: http://wwwmepgovsa/indexjsp;jsessionid=9BF35AD3E230209CDFF9 8BFE0BBC8675alfa?event=ArticleViewandArticleObjectID $=80$

Mostafa, M. M. 2005. Attitudes towards women managers in the United Arab Emirates: the effects of patriarchy, age and sex differences, Journal of Managerial Psychology 20(6): 522-540. http://dx.doi.org/10.1108/02683940510615451

Naffziger, D.; Hornsby, J.; Kuratko, D. 1994. A proposed research model of entrepreneurial motivation, Entrepreneurship Theory and Practice 18(3): 29-42.

Porter, M. E. 2009. Competitiveness and the state of entrepreneurship in Saudi Arabia, in The Global Competitiveness Forum, 25-27 January, 2009, Riyadh, Saudi Arabia.

Rees, J. R.; Althakhri, R. 2008. Organizational change strategies in the Arab region: a review of critical factors, Journal of Business Economics and Management 9(2): 123-132.

http://dx.doi.org/10.3846/1611-1699.2008.9.123-132

Reynolds, P. D. 2007. New firm creation in the United States: a PSED I overview, Foundations and Trends in Entrepreneurship 3(1): 1-149. http://dx.doi.org/10.1561/0300000010

Reynolds, P. D.; Camp, S. M.; Bygrave, W. D.; Autio, E.; Hay, M. 2002. Global entrepreneurship monitor: 2001 executive report. Babson Park/London: Babson College and London Business School.

Rosa, P.; Carter, S.; Hamilton, D. 1996. Gender as a determinant of small business performance: Insights from a British study, Small Business Economics 8(6): 463-478.

http://dx.doi.org/10.1007/BF00390031

Sadi, M. A.; Al-Ghazali, B. M. 2010. Doing business with impudence: a focus on women entrepreneurship in Saudi Arabia, African Journal of Business Management 4(1): 1-11.

Shabbir, A.; Di Gregorio, S. 1996. An examination of the relationship between women's personal goals and structural factors influencing their decision to start a business: the case of Pakistan, Journal of Business Venturing 11(6): 507-529. http://dx.doi.org/10.1016/S0883-9026(96)00034-1

Shane, S. 2009. Why encouraging more people to become entrepreneurs is bad economic policy, Small Business Economics 33(2): 141-149. http://dx.doi.org/10.1007/s11187-009-9215-5

Shane, S.; Kolvereid, L.; Westhead, P. 1991. An exploratory examination of the reasons leading to new firm formation across country and gender, Journal of Business Venturing 6(6): 431-446. http://dx.doi.org/10.1016/0883-9026(91)90029-D 
Shane, S.; Locke, E. A.; Collins, C. J. 2003. Entrepreneurial motivation, Human Resource Management Review 13(1): 257-279.

Shaver, K. G.; Scott, L. R. 1991. Person, process, choice: the psychology of new venture creation, Entrepreneurship Theory and Practice 16(2): 23-45.

Scheinberg, S.; MacMillan, I. 1988. An 11-country study of motivations to start a business, in B. A. Kirchoff, W. A. Long, W. E. McMullan, K. H. Vesper, Jr. W. E. Wetzel (Eds.). Frontiers of Entrepreneurship Research. Wellesley MA: Babson College, 669-684.

Schiller, B. R.; Crewson, P. E. 1997. Entrepreneurial origins: a longitudinal inquiry, Economic Inquiry 35(3): 523-531. http://dx.doi.org/10.1111/j.1465-7295.1997.tb02029.x

Steel, P.; König, C. J. 2006. Integrating theories of motivation, Academy of Management Review 31(4): 889-913. http://dx.doi.org/10.5465/AMR.2006.22527462

The World Factbook. 2010. Saudi Arabia [online], [cited 31 October 2010]. Available from Intermet: https://www.cia.gov/library/publications/the-world-factbook/geos/sa.html

Verheul, I.; Van Stel, A.; Thurik, R. 2006. Explaining female and male entrepreneurship at the country level, Entrepreneurship and Regional Development 18(2): 151-183.

http://dx.doi.org/10.1080/08985620500532053

\section{APPENDIX A}

\section{Survey items}

This study aims at exploring the attitudes of Saudi youth towards entrepreneurship (establishing a business). Please answer the following questions:

1. Sex:

2. Have you ever participated in starting a business?

3. Would you like to start a business (as owner)?

4. Have you had any qualifications to start a business(eg training)?

5. In case of starting a business, what is the most important reason to do so (you can choose more than one):
a. Financial gain
b. There is no other job
c. To be independent
d. To provide job opportunities
e. To have a higher social position
f. To be more flexible in the work
g. To use my creativity
h. To develop more experience
i. Self-achievement
j. To have control
$\mathrm{k}$. To achieve my vision

Male Female

Yes No

Yes No

Yes No 
Wafa N. ALMOBAIREEK (Ph.D in Business, Nottingham University, UK) is an Associate Professor of Marketing at King Saud University, Saudi Arabia, and Director of The Institute of Prince Salman for Entrepreneurship (IPSE) in KSU. Research and teaching interests include marketing, small businesses, and entrepreneurship. Dr. Almobaireek is an author of a number of books in the area of small businesses and Entrepreneurship. She is, currently, working on a series of studies and projects on Entrepreneurship for IPSE.

Tatiana S. MANOLOVA (DBA, Boston University) is an Associate Professor of Management at Bentley University, USA. Research and teaching interests include strategic management (competitive strategies for new and small companies), international entrepreneurship, and management in emerging economies. She is the author of over 35 scholarly articles and book chapters and is currently affiliated with Diana International, which explores growth strategies of women business-owners worldwide. 